УДК 81'38:42

DOI https://doi.org/10.26661/2414-9594-2021-1-24

\title{
МОВА ХУДОЖНЬОГО ТВОРУ ЯК ПРЕДМЕТ МОВНОСТИЛІСТИЧНОГО ДОСЛІДЖЕННЯ
}

\author{
Удовіченко Г. М. \\ кандидат педагогічних наук, \\ доиент кафедри іноземної філології, українознавства та соиіально-правових дисциплін \\ Донецький національний університет економіки і торгівлі \\ імені Михайла Туган-Барановського \\ вул. Трамвайна, 16, Кривий Ріг, Дніпропетровська область, Украӥна \\ orcid.org/0000-0003-3731-0857 \\ udovichenko@donnuet.edu.ua \\ Куц М. О. \\ кандидат педагогічних наук, \\ асистент кафедри іноземної філології, українознавства та соиіально-правових дисииплін \\ Донецький національний університет економіки і торгівлі \\ імені Михайла Туган-Барановського \\ вул. Трамвайна, 16, Кривий Ріг, Дніпропетровська область, Україна \\ orcid.org/0000-0001-9419-5926 \\ kuts_mo@donnuet.edu.ua
}

Ключові слова: художній текст, мовностилістичний аналіз, ідейно-художній задум, жанр, мовні засоби.
У статті розглянуто підходи дослідників-лінгвістів щодо визначення закономірностей перекладу творів різних жанрів та їхньої відмінності. Сформульовано визначення мовностилістичного аналізу. Виконано критичний аналіз підходів до мовностилістичного аналізу художнього тексту. Зазначено, що вітчизняні та закордонні критики відзначають появу великої кількості якісних творів, розрахованих на масового читача. Останнім часом такі твори все частіше стають предметом мовностилістичного аналізу. Одним із важливих чинників у процесі перекладу $є$ жанрова належність оригіналу, яка спрямовує перекладача на вибір відповідного мовно-стилістичного інструментарію. Переклад художніх творів вимагає ще більших зусиль перекладача для збереження задуму автора, передачі духу епохи, іiі культурних надбань тощо. Складність художнього перекладу зумовлює цілу низку нових завдань не лише для перекладача, а й для перекладознавчої науки загалом, передусім - стилістики.

Доведено, що в сучасних творах художньої літератури предмет мовностилістичного аналізу можна визначити як сукупність використаних у художньому творі мовних засобів, за допомогою яких письменник забезпечує втілення ідейно-художнього задуму; вивчення виразних засобів мови та стилістичних прийомів повинно враховувати взаємозв'язок застосування зазначених засобів і прийомів зі змістом художнього твору; мовні засоби та прийоми, які несуть стилістичну функцію, служать не тільки відповідній передачі художнього задуму, а й завданням автора. Для виконання поставлених завдань використовувалася комплексна методика аналізу, що включає прийоми порівняльного лінгвістичного аналізу, статистичного підрахунку мовних одиниць, класифікаційного аналізу, контекстуальної інтерпретації, виявлення смислових і конотативних відповідностей. Теоретична значущість дослідження полягає в подальшому розвитку порівняльного мовностилістичного аналізу оригінального художнього твору, призначеного для масового читача, i його перекладу, у встановленні основних стилістичних закономірностей, характерних для творів масової літератури. Практична значущість полягає в тому, що матеріал дослідження може використовуватися в курсах із порівняльної стилістики англійської та української мов, а також під час вивчення сучасної зарубіжної літератури у вишах. 


\title{
LANGUAGE OF LITERARY TEXT AS AN OBJECT OF LINGUISTIC RESEARCH
}

\author{
Udovichenko H. M. \\ Ph. D. in Pedagogy, \\ Associate Professor at the Department of Foreign Philology, \\ Ukrainian Studies and Social and Law Disciplines \\ Donetsk National University of Economics and Trade named after Mykhailo Tugan-Baranovsky \\ Tramvayna str., 16, Kryvyi Rih, Dnipropetrovsk region, Ukraine \\ orcid.org/0000-0003-3731-0857 \\ udovichenko@donnuet.edu.ua \\ Kuts M. O. \\ Ph. D. in Pedagogy, \\ Assistant of the Department of Foreign Philology, \\ Ukrainian Studies and Social and Law Disciplines \\ Donetsk National University of Economics and Trade named after Mykhailo Tugan-Baranovsky \\ Tramvayna str., 16, Kryvyi Rih, Dnipropetrovsk region, Ukraine \\ orcid.org/0000-0001-9419-5926 \\ kuts_mo@donnuet.edu.ua
}

Key words: literary text, linguistic and stylistic analysis, ideological and literary idea, genre, linguistic means.
The article considers the approaches of linguists to determine the patterns of translation of different genres works and their differences. The definition of linguistic-stylistic analysis is formulated. A critical analysis of approaches to linguistic and stylistic analysis of an artistic text is performed. It is noted that domestic and foreign critics mark the emergence of a large number of quality works designed for the mass reader. Recently, such works are increasingly becoming the subject of linguistic analysis. One of the important factors in the translation process is the genre affiliation of the original, which directs the translator to choose the appropriate linguistic and stylistic tools. The translation of literary works requires even greater efforts of the translator to preserve the author's intention, to convey the spirit of the era, its cultural heritage and so on. The complexity of literary translation determines a number of new tasks not only for the translator, but also for translation science in general, and stylistics in the first place.

It is proved that in modern works of fiction the subject of linguistic stylistic analysis can be defined as a set of linguistic means used in a work of art, by means of which the writer provides the embodiment of ideological and artistic idea; the study of expressive means of speech and stylistic techniques should take into account the relationship between the use of these tools and techniques with the content of the literary work; linguistic means and techniques that have a stylistic function, serve not only the appropriate transfer of artistic design, but also the task of the author. To perform the tasks, a comprehensive method of analysis was used, which includes methods of comparative linguistic analysis, statistical calculation of language units, classification analysis, contextual interpretation, identification of semantic and connotative correspondences. The theoretical significance of the study lies in the further development of comparative linguistic analysis of the original literary work intended for the mass reader, and its translation, in establishing the basic stylistic patterns characteristic of works of mass literature. The practical significance lies in the fact that the research material can be used in courses on comparative stylistics of English and Ukrainian languages, as well as in the study of modern foreign literature in universities.
Вступ. Стильова диференціація мови та мовлення, а також пов'язана 3 нею можливість відбору різних мовних засобів і мовних прийомів найяскравіше виступають у текстах художньої літератури. Художня література наочно підтвер- джує, що поняття точності, образності, експресивності, як і інші стилістичні категорії, не механічно перекочовують 3 одного мовного стилю в інший, а в системі кожного стилю набувають глибокої своєрідності. 
Розвиток сучасної літературної художньої творчості пов'язаний зі зміною сформованих жанрів і створенням нових. Вітчизняні та зарубіжні критики (О. Вайнштейн, Т. Введенська, Н. Купина, Т. Струкова, М. Черняк, J. Cawelty, M. Gannon) відзначають появу великої кількості якісних творів, розрахованих на масового читача. Такі твори поступово стають предметом мовностилістичного аналізу, i це ставить нові завдання перед стилістикою. Підхід і вимоги до перекладу зумовлюються типами текстів, що впливає на вибір прийомів перекладу та визначення ступеня еквівалентності перекладу оригіналу. Цілі та завдання перекладу, як відомо, залежать від жанру оригіналу. Кожен із жанрів має свої закономірності перекладу твору та свої відмінності [10, с 339]. В умовах розвитку нових жанрів від перекладу вимагається не тільки точність, збереження авторського задуму, але й здатність так само активно привертати й утримувати увагу читача, як це відбувається в оригінальних творах.

Актуальність дослідження зумовлюється також потребою у розвитку методів комплексного стилістичного аналізу художньої єдності «оригінал - переклад».

Мета дослідження полягає у виявленні й описі основних підходів до мовностилістичного аналізу художнього тексту.

Багаторічні лінгвістичні дослідження сформували різні методи відбору й обробки мовного матеріалу. Дослідження мови 3 погляду іiї функціонально-стилістичних властивостей почалося порівняно недавно $[7$, с. 6]. Активний розвиток лінгвістичної стилістики як самостійного розділу мовознавства припадає на середину минулого століття. Варто, однак, підкреслити, що ідеї, які визначили предмет і зміст стилістики, а також розвиток теорії художньої мови загалом, виникли набагато раніше та пов'язані з іменами Вільгельма фон Гумбольдта [4] і О. Потебні [8].

Аналіз досліджень цієї проблеми. Усі розділи мовознавства мають особливі об'єкти та предмети вивчення, які потребують для їх дослідження не лише загальнонаукових і загальномовних методів, але й спеціальних методів аналізу й опису конкретних мовних явищ. Лінгвостилістика закономірно не становить винятку. Українська лінгвостилістика - порівняно молода галузь мовознавства. Традиційно вважають, що іії становлення припадає на 20-30-ті pp. XX ст., а формування як окремої мовознавчої науки співвіднесене 3 50-60-ими рр. Зародження лінгвостилістичних студій загалом асоціативно пов'язують із працею Шарля Баллі «Трактат із французької стилістики» (1818 р.). Як особлива наукова дисципліна вона представлена вже у працях Празького лінгвістичного гуртка. На противагу літературознавчій стилістиці, лінгвостилістика зосереджує увагу на функціонально-стильовому розмаїтті стилістичних явищ як вияві специфіки відображення концептуальної картини світу в національно-мовній.

У слов'янській лінгвістиці формування стилістики як розділу науки про мову пов'язують передусім з іменами В. Виноградова, I. Гальперіна, Г. Винокура, Б. Томашевського, Л. Щерби й інших мовознавців. У працях цих учених закладено й обгрунтовано основні поняття сучасної стилістики, які потім усебічно розвинені в роботах їхніх послідовників (І. Арнольд, В. Задорнова, Н. Болотнова, О. Крилова).

Лінгвістична стилістика - наймолодша галузь мовознавчої науки, яка вивчає й аналізує стиль мови художніх творів, авторам яких властива багата «індивідуальна мовностилістична тональність» (І. Білодід). У цій галузі плідно працювали такі вчені: І. Білодід, С. Богдан, В. Ільїн, І. Грицютенко, Ф. Жилко, П. Тимошенко, В. Масальський, Г. Їжакевич, С. Криворучко, Н. Бойко, О. Калита, В. Ващенко, П. Плющ, Д. Баранник, Л. Мацько, С. Срмоленко й інші.

Відомо, що нині немає єдиної думки щодо питання про стиль, його основні характеристики та завдання стилістики. Визначення предмета стилістики досі пов'язане 3 певними відмінностями й навіть суперечностями, які також багато в чому залежать від різних тлумачень самого поняття «стиль» (Л. Бабенко, В. Виноградов, І. Гальперін, В. Звегинцев, А. Лосєв, Л. Нелюбін, Л. Новиков, М. Семенюк, О. Соколов, Н. Пелевіна, 3. Тураєва, Г. Поспєлов, О. Швейцер).

Виклад основного матеріалу дослідження. Насамперед варто врахувати те, що аналіз текстів різних функціональних стилів має також почасти свою специфіку. Найбільш повно в сучасній лінгвостилістиці розроблені прийоми та процедури, що застосовують у дослідженнях художніх текстів. Як слушно зауважує С. Єрмоленко, «лінгвостилістика розпочиналася 3 вироблення методів аналізу художнього тексту. Поширення лінгвостилістичного аналізу на засоби виразності мови в різних сферах спілкування, у різних мовних ситуаціях зумовило визначення різної мети стилістичних досліджень і методико-стилістичних напрямів, аспектів досліджень» [7, с. 15].

У своїх наукових розвідках О. Дубенко зауважує: «Якщо стилістика художнього мовлення, незважаючи на свій міждисциплінарний, а тому не до кінця визначений характер, так чи інакше завжди мала статус окремої галузі досліджень, то порівняльна стилістика художнього мовлення ніколи не була окремою дисципліною, хоча дослідження в цьому напрямі ведуться вже не одно десятиліття» [5, с. 157].

Не менше суперечностей щодо розуміння предмета та змісту стилістичного дослідження худож- 
нього твору (А. Єсін, Б. Мантиєва, В. Звегинцев, Г. Степанов, 3. Хованська, О. Швейцер, R. Crane). Суперечності в поглядах на предмет і зміст стилістики багато в чому послужили причиною появи особливого розділу філології - лінгвопоетики, яка прямо та безпосередньо стикається 3 лінгвостилістикою [8]. Визначення, яке було дано поняттю предмета лінгвопоетики, найбільше відповідає меті та завданням нашого дослідження, оскільки воно дає базові підстави мовностилістичного аналізу художнього твору. У лінгвопоетиці мовностилістичний аналіз художнього твору розуміють як аналіз сукупності «використаних у художньому творі мовних засобів, за допомогою яких письменник забезпечує естетичний вплив, необхідний для втілення ідейно-художнього задуму» [6, с. 59].

Грунтуючись на цьому підході, лінгвісти зазвичай розмежовують два типи досліджень. Метою досліджень одного з них виявляється «відтворення, за можливості, повної картини того, якими є тематико-стилістичні характеристики використання окремого художнього прийому в тому чи іншому творі, у групі творів тощо» $[8$, с. 8]. У дослідженнях першого типу зазвичай ставиться завдання розглянути максимально більшу кількість застосування обраного прийому, виявити найбільш загальні закономірності функціонування цього прийому. До зазначеного напряму можна віднести дослідження, присвячені особливостям обраного мовного образного засобу або групам засобів у творах різних авторів (Г. Винокур, В. Кухаренко, С. Мезенін, О. Міщанська, Г. Основіна).

Другий напрям «уособлює дослідження окремого художнього тексту, спрямоване на виявлення ролі формальних мовних елементів у передачі якогось ідейно-художнього змісту та у створенні певного естетичного ефекту» [8, с. 8]. Роботи, які можна віднести до цього напряму, вирізняє принципово важливе для стилістичного аналізу розуміння стилю «як якості мови» [3, с. 15]. Якість мови водночас виявляється найтіснішим чином пов'язаною 3 характером iï впливу на читача та слухача i досягненням бажаної реакції на той чи інший мовний текст, зокрема й художній твір (М. Блох, І. Гальперін, В. Дем'янков, В. Одинцов, Н. Остроушко, Н. Пєлєвіна, І. Шилова). Основною концепцією цього напряму є розуміння того, що використання обраного мовного вираження стилістично мотивовано художнім і композиційним задумом автора.

У свою чергу, цю концепцію зумовлює поняття єдності форми та змісту як однісї з невід'ємних властивостей художнього твору $[9$, с. 8]. Як зауважує Б. Томашевський, ця єдність не залежить від бажання й досвідченості автора. Сам собою зміст твору, як підкреслював В. Виноградов, «не $\epsilon$ предметом лінгвістичного вивчення. Мовознавця цікавлять способи вираження цього змісту. Але у плані такого вивчення і сам зміст не може залишитися зовсім поза увагою лінгвіста» [1, с. 14]. Значно пізніше цей принцип єдності форми і змісту був згаданий як непорушний автором книги "Style in Fiction" [15, c. 14].

Отже, вивчення виразних засобів мови та стилістичних прийомів повинно враховувати взаємозв'язок застосування зазначених засобів i прийомів зі змістом художнього твору. 3 огляду на цей зв'язок, лінгвіст виходить 3 того, що «правильність вибору слова є функцією мети висловлювання» [1, с. 14]. Автор книги "Style in Fiction" висловлює таку саму думку: " $<\ldots$..> within a text it is possible to be more specific about how language serves a particular artistic function" [8, с 13]. «Якщо мета висловлювання - затемнити думку або послабити значення слова, або представити зміст думки у сухій протокольній формі тощо, то й правильний вибір слів тут буде такий, який відповідає поставленому завданню, тобто слова будуть найбільш загальними, абстрактними зв вираженими ними значенням $<\ldots>$ » $[1$, с. 14$]$.

Ще раніше про вищезазначене писав Г. Винокур: «Те саме можна сказати або написати по-різному. Зміст, думка можуть залишатися водночас цілком незмінними, але змінюються тон і забарвлення самого викладу думки, а це, як відомо, істотно впливає на сприйняття змісту і зумовлює різні форми реакції на почуте або прочитане» [2, с. 16].

Сприйняття й реакція стають одними із провідних понять у стилістичних дослідженнях сучасних художніх творів. На підтвердження цього можна послатися на слова молодої американської письменниці Blair Hurley. Вона пише: "When asked what makes our favorite books our favorite books, sometimes we're hard pressed to find an answer. Often it's just a feeling that makes the book special a mood that is splendidly cultivated throughout the story and succeeds in immersing us in the world" [14]. Саме читацьке сприйняття, яке спирається на настрій, що пронизує все оповідання й занурює читача в його атмосферу, говорить про те, чи зумів автор захопити читача і створити книгу, яку можна полюбити.

Мовні засоби та прийоми, які виконують стилістичну функцію, служать не тільки відповідній передачі художнього задуму, а й завданням автора. Вони повинні сприяти реалізації функції впливу. Карен Х’юітт відзначає важливу роль таких засобів і пише: “A writer's language creates a world in which the reader participates in a unique relationship" [13, c. 11].

У зв'язку із цим необхідно розмежовувати поняття «естетичний вплив» $\mathrm{i}$ «функція впливу», особливо щодо сучасних творів fiction. У класичних роботах зі стилістики та лінгвопоетики під 
естетичним впливом розуміють такий вплив, який відповідає уявленням мовної спільноти «про прекрасне і потворне, піднесене і низинне, трагічне і комічне тощо» [12, с. 773]. Колись англійський поет Вільям Вордсворт писав, що читач має відчувати «складне відчуття насолоди» - complex feeling of delight - навіть тоді, коли він читає поему про скорботні почуття й нещасних людей. Complex feeling of delight, яке повідомляє автор читачеві за допомогою різноманітних стилістичних і композиційних засобів, дозволить пом'якшити почуття, викликані описами цих страждань. Карен X'юітт так передає слова В. Вордсворта: " $<\ldots>$ He argued that the reader, too, when reading a poem, should experience a "complex feeling of delight" which would soften the painful feelings aroused by "powerful descriptions of the deeper passions"" [13, c. 11].

Ще на початку XX ст. англійський критик i літературознавець Б. Такерман писав, що коли в того чи іншого твору є читацька аудиторія, то будьякий роман, незалежно від того, наскільки незначна тема і наскільки вимогливі читачі, має силу впливу саме тому, що автор привертає їхню увагу. "However poor your matter may be, however near you may come to that "foolishest of existing mortals", $<\ldots>$ still; if there be those who read your works, they will undoubtedly be- more or less influenced by what they find there. And it is because the novelist amuses that he is thus influential" [17, c. 174].

Це не $\epsilon$ секретом, що твори, розраховані на масового читача, відрізняються від так званої high-class literature [13, с. 88] не тільки дуже великими тиражами, а й типологізованими мовними та композиційними ознаками. Твори для масового читача, або bestsellers, до яких належать різні твори, іноді називають formula novels. Лінгвісти вважають, що для таких творів якість - the quality of writing - не має значення. У них важливі лише дія (action) і оригінальні ідеї (ingenuity) [13, с. 88].
Імовірно, формулювання Карен Х'юітт the quality of writing можна було б ототожнити 3 поняттям «якість мовлення». Беручи це ототожнення, важко буде погодитися, що слова у творах виконують тільки механічну функцію (mechanical function) [13, с. 88]. Інакше автори творів не змогли б впливати на читача й захопити його увагу, змусити стежити за сюжетом i дочитати книгу до кінця. Отже, сучасні твори впливають на читача, що відрізняється особливою інтерактивністю.

Необхідно також звернутися до поняття the common reader - «звичайний читач». Критики сучасної літератури (fiction) зазначають, що саме звичайний читач формує літературний канон $[13$, с. 77$]$. Твори, які популярні в масового читача, відрізняються своєю системою тематичних і стилістичних особливостей. На це, зокрема, вказується в дослідженні А. Ліпгарта [16]. У таких творах стиль існує не як сума елементів тексту, важливих в метасеміотичному плані, але як спосіб передачі змісту, зокрема й різні та взаємопов' язані типи оповіді всередині тексту [16, с. 10].

Висновки. Проведене дослідження свідчить про те, що сучасні твори художньої літератури (fiction) $є$ предметом мовностилістичного аналізу, який варто розуміти як аналіз сукупності всіх виразних засобів і стилістичних прийомів, за допомогою яких письменник утілює свій ідейно-художній задум і забезпечує необхідний вплив на читача або слухача. «Якість мови», що складається 3 різних композиційних і стилістичних чинників, привертає й утримує увагу читача, спонукає його до глибокого читання.

У сучасній літературі (fiction) твори, розраховані на масового читача, або bestsellers, занурюють читача у вигаданий авторами світ, змушують повірити в описувані події. Інакше кажучи, ці твори мають яскраво виражену функцію впливу.

\section{ЛІТЕРАТУРА}

1. Виноградов В. Язык художественного произведения. Bопросы языкознания. Москва, 1954. № 5. C. 10-28.

2. Винокур Г. О задачах истории языка. Ученые записки Московского городского педагогического института. 1941. Вып. 1. С. 89-120.

3. Гальперин И. Очерки по стилистике английского языка. Москва : Издательство литературы на иностранных языках, 1958. 459 с.

4. Гумбольдт В. Язык и философия культуры. Москва : Прогресс, 1985. 456 с.

5. Дубенко О. Порівняльна лінгвопоетика як автономна дисципліна філологічного циклу. Young Scientist. 2015. № 1 (16). С. 157-160.

6. Задорнова В. Словесно-художественное произведение на разных языках как предмет лингвопоэтического исследования : дис. ... докт. филол. наук: 10.02.04. Москва, 1992. 492 с.

7. Єрмоленко С. Методи стилістичних досліджень. Украйнська лінгвостилістика XX-початку XXI ст.: система понять і бібліографічні джерела / за ред. С. Срмоленко. Київ : Грамота, 2007. С. 13-17.

8. Липгарт А. Основы лингвопоэтики : учебное пособие. Москва : Изд-во МГУ, 2006. 109 с.

9. Потебня А. Теоретическая поэтика. Москва : Высшая школа, 1990. 384 с.

10. Томашевский Б. Стилистика и стихосложение. Ленинград : Учпедгиз, 1959. 408 с. 
11. Федоров А. Основы общей теории перевода. Лингвистические проблемы : учебное пособие для студентов институтов и факультетов иностранных языков. Москва : Филология ; Санкт-Петербург : Филологический факультет СПбГУ, 2002. 416 с.

12. Философский энциклопедический словарь. Москва : Советская Энциклопедия, 1989. 356 с.

13. Hewitt K. Analyzing Literature: Language, Meaning and Metaphor. Understanding English Literature. Oxford : Perspective Publications Ltd., 2008. P. 4-17.

14. Hurley B1. Mood and Consistency in Fiction. URL: http://languagestyle.suitel01.com/article.cfm/ moodandconsistencyinfiction (дата звернення: 11.03.2021).

15. Leech G. Style in Fiction: A linguistic Introduction to English Fictional Prose. 2'nd edition. Harlow : Pearson Education Limited, 2007. 402 p.

16. Lipgart A. Parody and Style. On "The Da Vinci Code" by Dan Brown, "The Asti Spumante Code" by Toby Clements and the "Va Dinci Cod" by A.R.R.R. Roberts. Moscow : KomKniga, 2007. 152 p.

17. Tuckerman B. A History of English Prose Fiction. General Books, 2009. 310 p.

\section{REFERENCES}

1. Vinogradov, V.V. (1954) Yazyk khudozhestvennogo proizvedeniya [The language of a literary work]. Questions of linguistics. Mockow, № 5. Pp. 10-28.

2. Vinokur, G.O. (1941) O zadachakh istorii yazyka [On the tasks of the history of language]. Scientific notes of the Moscow City Pedagogical Institute. Moscow, Moscow State Pedagogical University, Vol. 1, T. V. Pp. 89-120.

3. Gal'perin, I.R. (1958) Ocherki po stilistike angliyskogo yazyka [Essays on the stylistics of the English language.]. Moscow, Publishing house of literature in foreign languages, $459 \mathrm{p}$.

4. Gumbol'dt, V. (1985) Yazyk i filosofiya kul'tury [Language and philosophy of culture]. Moscow, Progress Publ., $456 \mathrm{p}$.

5. Zadornova, V.Ya. (1992) Slovesno-khudozhestvennoye proizvedeniye na raznykh yazykakh kak predmet lingvopoeticheskogo issledovaniya: dis. ... d-ra filol. nauk: 10.02.04 [Literary work in different languages as a subject of linguopoetic research: dissertation Dr. Filol. Sciences: 10.02.04]. Moscow, $492 \mathrm{p}$.

6. Dubenko, O.Yu. (2015). Porivnialna linhvopoetyka yak avtonomna dystsyplina filolohichnoho tsyklu [Porivnialna linhvopoetyka yak avtonomna dystsyplina filolohichnoho tsyklu]. Young Scientist, № 1 (16), pp. 157-160.

7. Yermolenko, S.Ya. (2007) Metodi stilistichnikh doslidzhen [Methods of stylistic research]. Ukrainian linguistic stylistics of the XX-beginning of the XXI century: system of concepts and bibliographic sources. Kyiv, Gramota Publ., 2007, pp. 13-17.

8. Lipgart, A.A. (2006) Osnovy lingvopoetiki: ucheb. posob. [Fundamentals of linguopoetics: manual]. Moscow: Moscow State University Publishing House, 109 p.

9. Potebnya, A.A. Teoreticheskaya poetika [Theoretical poetics]. Moscow, Higher School, 384 p.

10. Tomashevskiy, B.V. (1959) Stilistika i stikhoslozheniye [Stylistics and versification]. Leningrad: Uchpedgiz, 408 p.

11. Fedorov, A.B. (2002) Osnovy obshchey teorii perevoda. Lingvisticheskiye problemy: ucheb. posob. dlya stud. in-tov i f-tov in. yaz. [Foundations of the general theory of translation. Linguistic problems: textbook. manual. for students of institutes and faculties of foreign languages] Moscow: Philology; St. Petersburg: Faculty of Philology, St. Petersburg State University, 416 p.

12. Filosofskiy entsiklopedicheskiy slovar' (1989) [Philosophical Encyclopedic Dictionary]. Moscow, Soviet Encyclopedia $356 \mathrm{p}$.

13. Hewitt, K. (2008) Analyzing Literature: Language, Meaning and Metaphor. Understanding English Literature. Oxford: Perspective Publications Ltd., pp. 4-17.

14. Hurley, B1. Mood and Consistency in Fiction. Available at: http://languagestyle.suitel01.com/article.cfm/ mood and consistency in ficti on (Last accessed: 11.03.2021).

15. Leech, G. (2007) Style in Fiction: A linguistic Introduction to English Fictional Prose. 2nd edition. Harlow: Pearson Education Limited, 402 p.

16. Lipgart, A. A. (2007) Parody and Style. On "The Da Vinci Code" by Dan Brown, "The Asti Spumante Code" by Toby Clements and the "Va Dinci Cod" by A.R.R.R. Roberts. Moscow: KomKniga, 152 p.

17. Tuckerman, B. (2009) A History of English Prose Fiction. General Books, 310 p. 